\title{
Aetiology of idiopathic scoliosis: the "scotch type" effect or the abnormal initial local anterior-lateral conjunction between the dura mater spinalis and the periosteum of spinal canal of concave side. New evidence
}

\author{
Valerii Drobyshevskiy \\ From 11th International Conference on Conservative Management of Spinal Deformities - SOSORT 2014 \\ Annual Meeting \\ Wiesbaden, Germany. 8-10 May 2014
}

\section{Background information}

Early we described a local internal lateral fixation (LILF) of a dura mater spinalis to the wall of the vertebral channel as the main reason of the serious idiopathic scoliosis.

There are a postmortal investigations of the serious scoliosis with a LILF of duramater. Early it was considered by other author that this a secondary phenomenon as a consequence of the vertebras edges pressure in the vertebral channel towards the dura mater.(Movshovich I.,1964 [1]).

\section{Purpose}

First, to prove that the LILF is not the secondary phenomenon, on the contrary, the LILF of dura mater like a hooked bowstring causes a serious idiopathic scoliosis.

Second, to find a trace on MRI of flat tension of dura mater in consequence of conjunction between the Dura matter and the Periosteum of spinal canal of concave side.

\section{Method}

Now we analyzed the evolution of the vertebral foramen forms on 10 postmortal cases of the serious idiopathic scoliosis and 30 MRI-tests of the initial little idiopahtic scoliosis with "bad scenario" or the intramedullar cyst.

G.I.Turner Scientific and Research Institute for Children's Orthopaedics, StPetersburg, Russian Federation 
doi:10.1186/1748-7161-9-S1-019

Cite this article as: Drobyshevskiy: Aetiology of idiopathic scoliosis: the "scotch type" effect or the abnormal initial local anterior-lateral

conjunction between the dura mater spinalis and the periosteum of spinal canal of concave side. New evidence. Scoliosis 2014 9(Suppl 1): 019.

Submit your next manuscript to BioMed Central and take full advantage of:

- Convenient online submission

- Thorough peer review

- No space constraints or color figure charges

- Immediate publication on acceptance

- Inclusion in PubMed, CAS, Scopus and Google Scholar

- Research which is freely available for redistribution

Submit your manuscript at www.biomedcentral.com/submit 